ORIGINAL ARTICLE

\title{
Seeds of sacha inchi (Plukenetia volubilis, Euphorbiaceae) as a feed ingredient for juvenile tambaqui, Colossoma macropomum, and matrinxã, Brycon amazonicus (Characidae)
}

\author{
Thyssia Bomfim ARAÚJO-DAIRIKI ${ }^{1}$, Francisco Célio Maia $\mathrm{CHAVES}^{2}$, Jony Koji DAIRIKI ${ }^{2}$ \\ Universidade Nilton Lins, Avenida Professor Nilton Lins 3259, Parque das Laranjeiras, CEP 69058-030 Manaus, Amazonas, Brasil \\ 2 Embrapa Amazônia Ocidental, Rodovia AM 010, Km 29, Caixa Postal 319, CEP 69010-970 Manaus, Amazonas, Brasil \\ * Corresponding author: jony.dairiki@embrapa.br
}

\section{ABSTRACT}

Sacha inchi (Plukenetia volubilis) is a plant native to the Peruvian Amazon with seeds that contain 24 to $29 \%$ protein, and levels of vitamin $\mathrm{A}$ and $\mathrm{E}$ and omega 3 polyunsaturated fatty acids that are suitable for fish nutrition. Thus, this study aimed to evaluate the use of sacha inchi seeds as an ingredient in the diets of tambaqui (Colossoma macropomum) and matrinxã (Brycon amazonicus). The acceptance and effect of three levels of sacha inchi seed meal $(0,15$ and $30 \%)$ in fish feed was evaluated in a randomized experiment, testing groups of 12 juvenile tambaquis $(29.8 \pm 1.0 \mathrm{~g}, 11.0 \pm 1.4 \mathrm{~cm})$ and groups of eight juvenile matrinxás $(34.8 \pm 1.3 \mathrm{~g}, 13.7 \pm 1.0 \mathrm{~cm})$. Growth performance and body composition of the fish were determined at the end of the experiment. An effect of the sacha inchi diet was only observed for feed conversion of tambaquis, which was worst at the highest level of sacha inchi seed. In conclusion, sacha inchi can be added to feed juvenile tambaquis at a level of $15 \%$, and juvenile matrinxâs at 30\% without compromising growth performance and body parameters of the fish.

KEYWORDS: alternative diet, growth performance, nutrition, fish

\section{Sementes de sacha inchi (Plukenetia volubilis, Euphorbiaceae) em rações para juvenis de tambaqui, Colossoma macropomum, e matrinxã, Brycon amazonicus (Characidae)}

\section{RESUMO}

Sacha inchi (Plukenetia volubilis) é uma planta nativa da Amazônia peruana cujas sementes contém 24-29\% de proteína, além de vitamina A e E e ácidos graxos polinsaturados ômega 3 em níveis adequados para a nutrição de peixes. Dessa forma, este estudo teve como objetivo avaliar o uso de sementes de sacha inchi como ingrediente em raçóes para o tambaqui (Colossoma macropomum) e matrinxã (Brycon amazonicus). Níveis de inclusão de sacha inchi nas raçóes e aceitação foram avaliados em um delineamento experimental inteiramente aleatorizado, avaliando três grupos de 12 juvenis de tambaqui $(29,8 \pm 1,0 \mathrm{~g} ; 11,0$ $\pm 1,4 \mathrm{~cm})$ e três grupos de oito juvenis de matrinxãs $(34,8 \pm 1,3 \mathrm{~g} ; 13,7 \pm 1,0 \mathrm{~cm})$ alimentados com raçóes contendo 0,15 ou $30 \%$ de farelo de sementes de sacha inchi. O crescimento e a composição corporal dos peixes foram avaliados ao final do experimento. Um efeito da ração com sacha inchi foi somente observado para a conversão alimentar de tambaquis, que foi pior no maior nível de semente de sacha inchi. Em conclusão, sacha inchi pode ser adicionada na alimentação de juvenis de tambaqui até o nível de 15\% e na de juvenis de matrinxã até 30\% sem comprometimento do desempenho e dos parâmetros corporais.

PALAVRAS-CHAVE: dieta alternativa, desempenho, nutrição, peixes 


\section{INTRODUCTION}

Tambaqui (Colossoma macropomum) and matrinxã (Brycon amazonicus) are fish species native to the Amazon region that are produced in semi-intensive aquaculture and are important economic alternatives in northern Brazil (Arbeláez-Rojas et al. 2002, Sebrae 2015). Tambaqui is the main native fish farmed in Brazil, for its meat of high quality and good taste. Its production increased from 8,000 to 135,858 tons from 1994 to 2015 and continues to grow. Tambaqui currently accounts for $28.1 \%$ of the fish farmed in Brazil. In the Amazonas state, in northern Brazil, 15,000 tons of fish are produced in aquaculture, largely involving rearing and growth of tambaquis in dugout ponds (IBGE 2015). Tambaquis are favorable for aquaculture due to their rusticity and rapid growth. Tambaqui is naturally resilient, tolerates low concentrations of dissolved oxygen and is resistant to sudden changes in $\mathrm{pH}$ (Aride et al. 2007; Silva et al. 2007; Dairiki and Silva 2011). About $80 \%$ of tambaqui currently commercialized is produced in captivity (Jacometo et al. 2010). The production of matrinxá production was of 9,366,203 tons in 2015 (IBGE 2015). This number may increase since this fish is in high demand by consumers due to its favorable organoleptic characteristics (taste and meat color) and high farming feasibility, with established technology for reproduction, management and growth (Honczaryk and Inoue 2009). Tambaqui and matrinxã are omnivorous and accept ingredients of vegetable origin. However, the feeding behaviour of the two species differs in the acceptance and consumption of diets formulated with unconventional ingredients.

Sacha inchi (Plukenetia volubilis) belongs to the plant family Euphorbiaceae, native to Central and South America. It is commercially cropped in the Peruvian Amazon, and Brazil has potential to produce this plant. Its seeds contain 24 to $29 \%$ protein, nearly 41.4\% oil (Gutiérrez et al. 2011; Souza et al. 2013; Rodriguez et al. 2015) and high levels of vitamin A and E (Fanali et al. 2011), making it suitable for dietary use. In addition, sacha inchi oil is highly nutritious, containing 45\% omega 3 polyunsaturated fatty acids (PUFA) (linolenic acid) (Guillén et al. 2003; Céspedes 2006; Clavijo et al. 2015). Beneficial effects of these fatty acids include the ability to prevent cardiovascular disorders, lower glyceride levels and antithrombotic action (Garmendia et al. 2011; Maurer et al. 2012, Catalán et al. 2015). Sacha inchi leaves and oil, as well as the presscake produced using oil extracted from its seeds, are an excellent option of a sustainable ingredient for omnivorous fish feeds. Cold pressed sacha inchi oil has high commercial value and is non-toxic to animals (Gorriti et al. 2010), making it a suitable ingredient for animal nutrition. In Amazonas state, in northern Brazil, tambaqui and matrinxã farming is an important small family business (Almudi and Pinheiro 2015), therefore there is a demand for the use of local, low-cost ingredients in tambaqui and matrinxã feeds, since conventional ingredients are expensive and come from different regions, increasing production costs (Dairiki and Silva 2011; Dairiki et al. 2013). The nutrient and energy balance of fish feeds, which is determined by the proportion of different feed ingredients, are fundamental aspects in fish production that directly affect carcass quality (Portz and Furuya 2012).

Tropical fish in general do not exhibit a high highly unsaturated fatty acids (HUFA) content in the body, but can convert PUFAs such as linolenic acid into HUFA by desaturation and elongation. Fish oil is the fish feed ingredient with the highest PUFA and HUFA levels; however, its high costs makes it difficult to obtain and it can become unsustainable, stimulating the search for novel diet ingredients. Flaxseed oil is a potential candidate for use in tropical fish feed. In fact, the carcass quality of jundias (Rhamdia quelen) improved with dietary flaxseed inclusion (Vargas et al. 2008). In addition, vegetable ingredients can be more suitable than those of animal origin. Using sensory analysis Stone et al. (2011) found that acceptance and preference for rainbow trout fillets by testers was higher for fish fed diets containing rapeseed oil as opposed to fish oil. In northern Brazil, flaxseed oil is not a feasible ingredient given its high cost and unavailability. As such, the inclusion of vegetable oils, presscake and/or oilseeds from non-traditional or local plants may be an excellent strategy to provide PUFA for bioconversion and thus improve lipidic quality in the carcass and/or fillets of tropical fishes.

Considering the omnivorous habits of both tambaqui and matrinxâ, and that sacha inchi is easily available from the Amazonian biodiversity, we hypothesize that the seeds of sacha inchi may be a convenient and nutritious option for use in the composition of feeds in both species' aquaculture. Therefore, this study aimed to evaluate the effect of different proportions of sacha inchi seed meal in the feed on the growth performance and body composition of juveniles of tambaqui and matrinxá.

\section{MATERIAL AND METHODS}

The experiment was carried out in the Aquaculture Division of Embrapa Western Amazon, Manaus, Amazonas state, Brazil (0306'07"S, 6001'30"W), from January to March 2013, in a two-factorial (fish species $\mathrm{x}$ feed) completely randomized design. The experimental units (replicates) consisted of a group of 12 juvenile tambaquis $(29.8 \pm 1.0 \mathrm{~g}$ initial weight and $11.0 \pm 1.4 \mathrm{~cm}$ initial length) and a group of eight juvenile matrinxâs $(34.8 \pm 1.3 \mathrm{~g}$ initial weight and $13.7 \pm 1.0 \mathrm{~cm}$ initial length). There were three replicates for each species and each of three feeds tested (see below), totaling 18 replicates. Fish were obtained from a commercial hatchery and allowed to adapt to experimental conditions for one week. For initial biometric assessment, fish were anesthetized in benzocaine solution (500 $\mathrm{mg} \mathrm{L}^{-1}$ water), weighted, measured using the ictiometer and kept during the whole experimental period in eighteen 310 $\mathrm{L}$ polypropylene tanks in a closed water recirculation system, with partial water replacement and forced aeration produced by a blower and air stones. 
Six test feeds were produced, three for matrinxãs and three for tambaquis. Diets were based on formulations specifically developed for matrinxãs (Izel et al. 2004) and tambaquis (Oishi et al. 2010). The three feeds for each species contained similar nitrogen and energy levels, but each one contained a different proportion of sacha inchi $(0,15$ and $30 \%)$ (Table 1). To produce the feed, sacha inchi seeds were ground and sieved to obtain seed meal, which was mixed with the other ingredients. The mixture was homogenized, added to $10 \%$ water and pelletized using an industrial grinder. Pellets of 3 to $4 \mathrm{~mm}$ were dried in a forced circulation oven $\left(45^{\circ} \mathrm{C}\right.$ for $24 \mathrm{~h}$ ). Feed was stored at $-20^{\circ} \mathrm{C}$ in hermetic containers and portions used in daily feeding were weighed immediately before use and kept in coolers.

Fish were given the test feeds for 60 days, receiving two daily meals $(8 \mathrm{~h}$ and $15 \mathrm{~h}$ ) until satiety. Water quality parameters $(\mathrm{pH}$, dissolved oxygen, temperature) were monitored daily. Nitrite, total ammonia, alkalinity and hardness were monitored monthly. The tanks were cleaned weekly by siphoning. To evaluate growth performance, at the end of the experiment fish were assessed to determine final weight, weight gain (WG = final weight - initial weight), feed intake (the total amount of feed consumed after the 60 days per experimental unity), feed conversion ratio (FCR = feed intake/weight gain), specific growth rate $[S G R=(\ln$ final weight $-\ln$ initial weight $) /$ time $\mathrm{x} 100]$ and survival $[S=$ (final number of fish - initial number of fish) $\times 100$ ]. In addition, four fish from each experimental unity were euthanized using a benzocaine overdose $(5,000 \mathrm{mg}$ $\mathrm{L}^{-1}$ water). The liver, adipose tissue and viscera were removed by abdominal laparotomy and weighed to determine body composition using the hepatosomatic (HIS = liver weight / carcass weight $\mathrm{x} 100$ ), liposomatic (LSI = intraperitoneal fat/ carcass weight $\times 100$ ), and vicerosomatic indices (VSI = viscera weight / carcass weight $\times 100$ ). Acceptance was estimated by the consumption of the experimental feeds. Data were submitted to exploratory analysis by outlier data test, variance homogeneity, range of the response variable, and analyzed by ANOVA followed by the Tukey test to contrast means $(\alpha=0.05)$ using the SAS statistical package.

\section{RESULTS}

Mean water temperature $\left(27.3 \pm 0.6^{\circ} \mathrm{C}\right)$, dissolved oxygen $(7.1$ $\left.\pm 0.4 \mathrm{mg} \mathrm{L}^{-1}\right), \mathrm{pH}(5.1 \pm 0.5)$, nitrite $\left(0.04 \pm 0.11 \mathrm{mg} \mathrm{L}^{-1}\right)$, total ammonia $\left(0.19 \pm 0.18 \mathrm{mg} \mathrm{L}^{-1}\right)$, alkalinity $\left(2.90 \pm 0.92 \mathrm{mg} \mathrm{L}^{-1}\right.$ $\left.\mathrm{CaCO}_{3}\right)$ and water hardness $\left(5.78 \pm 1.55 \mathrm{mg} \mathrm{L}^{-1} \mathrm{CaCO}_{3}\right)$ were within the range established by Gomes et al. (2005), Gomes and Urbinatti (2005) and Dairiki and Silva (2011) for both species. During the experiment, sacha inchi acceptance and the growth performance of juvenile tambaquis and matrinxâs were satisfactory according to the criteria of Arbeláez-Rojas

Table 1. Formulation and calculated composition (\%) of test feeds for tambaqui and matrinxã with 0, 15 and 30\% sacha inchi levels (as fed basis).

\begin{tabular}{|c|c|c|c|c|c|c|}
\hline \multirow{2}{*}{ Ingredient } & \multicolumn{3}{|c|}{ Tambaqui feed } & \multicolumn{3}{|c|}{ Matrinxã feed } \\
\hline & $0 \%$ & $15 \%$ & $30 \%$ & $0 \%$ & $15 \%$ & $30 \%$ \\
\hline Soybean meal & 46.59 & 43.50 & 37.82 & 36.93 & 30.90 & 33.43 \\
\hline Ground corn & 30.27 & 20.00 & 0.00 & 19.65 & 0.00 & 10.00 \\
\hline Wheat meal & 10.00 & 1.85 & 5.91 & 30.00 & 34.82 & 0.72 \\
\hline Meat and bone meal & 10.00 & 10.00 & 10.00 & 10.00 & 10.00 & 10.00 \\
\hline Soybean oil & 0.04 & 0.00 & 0.00 & 0.32 & 0.00 & 0.00 \\
\hline Dicalcium phosphate & 2.00 & 2.00 & 2.00 & 2.00 & 2.00 & 2.00 \\
\hline Mineral Premix $x^{(1)}$ & 0.50 & 0.50 & 0.50 & 0.50 & 0.50 & 0.50 \\
\hline Vitamin Premix ${ }^{(2)}$ & 0.50 & 0.50 & 0.50 & 0.50 & 0.50 & 0.50 \\
\hline Common salt & 0.10 & 0.10 & 0.10 & 0.10 & 0.10 & 0.10 \\
\hline Inert (kaolin) & 0.00 & 6.55 & 13.17 & 0.00 & 6.18 & 12.75 \\
\hline Total & 100 & 100 & 100 & 100 & 100 & 100 \\
\hline Ash (\%) & 9.41 & 15.85 & 22.04 & 8.63 & 14.36 & 21.55 \\
\hline Crude energy (kcal kg-1) & 3,894 & 3,894 & 3,894 & 3,900 & 3,900 & 3,900 \\
\hline Ether extract (\%) & 3.18 & 10.17 & 17.25 & 3.63 & 10.42 & 17.36 \\
\hline Crude fiber (\%) & 4.37 & 4.95 & 6.29 & 5.39 & 6.78 & 5.76 \\
\hline Crude protein (\%) & 30.00 & 30.00 & 30.00 & 28.00 & 28.00 & 28.00 \\
\hline \multicolumn{7}{|c|}{ 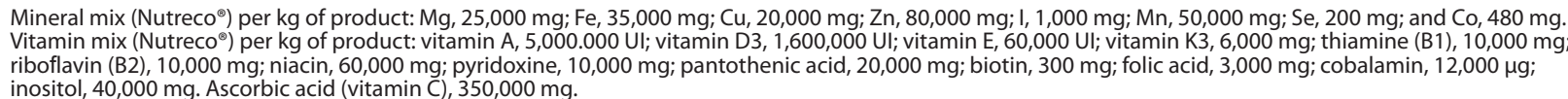 } \\
\hline
\end{tabular}


et al. (2002). No statistical differences were detected among treatments in the evaluated growth parameters, except for FCR in tambaquis, which was significantly lower for the 30\% sacha inchi feed in relation to the sacha inchi-free feed (0\%). No statistical differences were detected among treatments for survival, HSI, LSI and VSI (Table 2).

\section{DISCUSSION}

Feed intake parameters showed that both tambaquis and matrinxãs accepted the feeds containing sacha inchi, and survival, growth and body composition of fish generally did not differ significantly from feeds without sacha inchi $(0 \%)$. These results indicate that sacha inchi does not affect negatively nor improve significantly the development of tambaqui and matrinxã over commercially available feed. Thus, considering the cost-benefit relation, sacha inchi has the potential of being a cost-effective and alternative as a fish feed ingredient in the Amazon region.

Even in laboratory conditions, the growth performance of the matrinxã and tambaqui juveniles was satisfactory according to Izel et al. (2004) and Dairiki et al. (2013), respectively. Juvenile matrinxâs submitted to feed deprivation exhibited full compensatory growth in relation to animals fed daily by increasing feed intake and efficiency, leading to the conclusion that the use of intermittent cycles of feeding can be employed to reduce production costs (Urbinati et al. 2014). In our experiment the animals were fed daily and the feed intake did not differ among the treatments.
In other feed tests of matrinxã that used similar initial weight of juveniles and evaluation periods, but only commercial extruded feed (Arbelaez-Rojas et al. 2011; Urbinati et al. 2014) the growth performance of fish was better than in our study. The same discrepancy in growth rates was observed for juvenile tambaqui (Chagas et al. 2013; Silva and Fujimoto 2015) in comparison with our results. These observations show clearly the necessity to adapt the experimental feed tested in our study to the nutrition performance of commercial extruded feed. The significantly lower feed convertion rate of the 30\% sacha inchi feed in relation to the control feed in tambaqui suggests that higher concentrations of sacha inchi might have some inhibitory effect, that may be due the elevated crude fiber content of sacha inchi (6.29\%). The amount of feces siphoned from tanks housing tambaquis fed 30\% sacha inchi diets was higher than in the other treatments.

Our results open the prospect for the use of sacha inchi in aquaculture fish nutrition, which is a good alternative given the high content of crude protein and oil rich in omega 3 PUFA - linolenic acid (see Table 1). Like other vertebrates, fish cannot produce linoleic (18:2 $n-6)$ and linolenic acid (18:3 $n-3)$ and therefore need to obtain these essential fatty acids from their diet, according to species-specific requirements (New 1987; Valenzuela et al. 2014). Fish can convert 18-carbon PUFA into highly unsaturated fatty acids (HUFA) of the same omega 3 series, namely eicosapentanoic acid (EPA; 20:5 n-3) and docosaexanoic acid (DHA; 22:6 n-3) (Vargas et al. 2008; Tanamati et al. 2009; Kamarudin et al. 2012). In human nutrition, HUFAs are associated with the prevention

Table 2. Growth performance and body composition indices of juvenile tambaqui and matrinxã fed diets containing 0,15 and $30 \%$ sacha inchi levels. IW $=$ initial weight, $\mathrm{FW}$ = final weight, $\mathrm{Fl}$ = feed intake, WG = weight gain, $\mathrm{FCR}$ = feed conversion ratio, SGR = specific growth rate, $\mathrm{TL}$ = total length, $\mathrm{HSI}=$ hepatosomatic index, $\mathrm{LSI}=$ liposomatic index $\mathrm{VSI}=$ viscerosomatic index and $\mathrm{S}=$ survival. Values are means followed by the standard deviation. Superscripts for FCR of tambaquis denote significant differences (Tukey's test, $\mathrm{p}<0.05$ ).

\begin{tabular}{|c|c|c|c|c|c|c|}
\hline \multirow{2}{*}{ Variable } & \multicolumn{3}{|c|}{ Tambaqui feed } & \multicolumn{3}{|c|}{ Matrinxã feed } \\
\hline & $0 \%$ & $15 \%$ & $30 \%$ & $0 \%$ & $15 \%$ & $30 \%$ \\
\hline $\mathrm{IW}_{\text {lot }}(\mathrm{g})$ & $352.0 \pm 5.3$ & $355.3 \pm 13.3$ & $364.7 \pm 16.2$ & $288.7 \pm 3.1$ & $269.0 \pm 7.0$ & $277.3 \pm 9.4$ \\
\hline $\mathrm{IW}_{\text {unitary }}(\mathrm{g})$ & $29.3 \pm 0.4$ & $29.6 \pm 1.1$ & $30.4 \pm 1.3$ & $36.1 \pm 0.4$ & $33.6 \pm 0.9$ & $34.7 \pm 1.2$ \\
\hline $\mathrm{FW}_{\mathrm{lot}}(\mathrm{g})$ & $615.3 \pm 12.7$ & $577.3 \pm 104.5$ & $511.3 \pm 27.1$ & $460.0 \pm 25.0$ & $458.0 \pm 20.8$ & $484.0 \pm 46.8$ \\
\hline $\mathrm{FW}_{\text {unitary }}(\mathrm{g})$ & $51.3 \pm 1.1$ & $48.1 \pm 8.7$ & $42.6 \pm 2.3$ & $57.5 \pm 3.1$ & $57.3 \pm 2.6$ & $63.2 \pm 5.5$ \\
\hline $\mathrm{Fl}_{\text {lot }}(\mathrm{g})$ & $386.3 \pm 2.4$ & $395.4 \pm 91.4$ & $359.7 \pm 39.9$ & $314.8 \pm 28.2$ & $355.4 \pm 24.0$ & $370.5 \pm 22.7$ \\
\hline $\mathrm{FI}_{\text {unitary }}(\mathrm{g})$ & $32.2 \pm 0.2$ & $33.0 \pm 7.6$ & $30.0 \pm 3.3$ & $39.4 \pm 3.52$ & $44.4 \pm 3.0$ & $48.4 \pm 2.8$ \\
\hline$W_{\text {lot }}(g)$ & $263.3 \pm 7.6$ & $222.0 \pm 92.4$ & $146.7 \pm 42.7$ & $171.3 \pm 26.9$ & $189.0 \pm 15.1$ & $206.7 \pm 50.3$ \\
\hline$W G_{\text {unitary }}(\mathrm{g})$ & $21.9 \pm 0.6$ & $18.5 \pm 7.7$ & $12.2 \pm 3.6$ & $21.4 \pm 3.4$ & $23.6 \pm 1.9$ & $28.6 \pm 4.9$ \\
\hline FCR & $1.5 \pm 0.1^{b}$ & $1.9 \pm 0.5^{5 \mathrm{~b}}$ & $2.6 \pm 0.6^{a}$ & $1.8 \pm 0.1$ & $1.9 \pm 0.1$ & $1.8 \pm 0.3$ \\
\hline SCR $\left(\%\right.$ day $\left.^{-1}\right)$ & $1.2 \pm 0.1$ & $1.1 \pm 0.3$ & $0.8 \pm 0.2$ & $1.0 \pm 0.1$ & $1.2 \pm 0.1$ & $1.2 \pm 0.2$ \\
\hline $\mathrm{TL}(\mathrm{cm})$ & $14.1 \pm 1.1$ & $14.1 \pm 1.6$ & $13.7 \pm 1.3$ & $16.2 \pm 1.1$ & $16.1 \pm 1.6$ & $16.4 \pm 1.2$ \\
\hline HSI (\%) & $2.6 \pm 0.5$ & $2.2 \pm 0.3$ & $1.6 \pm 0.3$ & $2.0 \pm 0.6$ & $1.4 \pm 0.3$ & $1.7 \pm 0.3$ \\
\hline LSI (\%) & $0.1 \pm 0.2$ & $0.3 \pm 0.3$ & $0.5 \pm 0.6$ & $0.1 \pm 0.3$ & $0.2 \pm 0.3$ & $0.2 \pm 0.4$ \\
\hline VSI (\%) & $7.4 \pm 1.2$ & $7.2 \pm 1.1$ & $7.6 \pm 0.7$ & $9.7 \pm 2.5$ & $8.6 \pm 3.1$ & $8.2 \pm 1.6$ \\
\hline $\mathrm{S}(\%)$ & 100.00 & 100.00 & 100.00 & 100.00 & 100.00 & 95.8 \\
\hline
\end{tabular}


of a number of diseases and therefore the promotion of health benefits (Catalán et al. 2015). Cold-water marine fish exhibit adequate levels of HUFAs, which are mainly obtained from the diet (Garcia et al. 2012). The fatty acid composition of Atlantic cod (Gadus morhua) tissue can be regulated by mixing different plant or animal fats into their diets (Jobling et al. 2008). Rainbow trout (Oncorhynchus mykiss) fed flaxseed oil, which is also rich in omega 3 , accumulate this fatty acid series primarily in the carcass $(58.1 \%$ ), whereas $29.5 \%$ of PUFA is oxidized and only $12.4 \%$ bioconverted into HUFA (Turchini and Francis 2009). Future studies will focus on testing the incorporation of fatty acids in tambaqui and matrinxâ meat.

\section{CONCLUSIONS}

The present study indicates that seed meal of sacha inchi can be included in fish feed at levels up to $15 \%$ for juvenile tambaqui and $30 \%$ for matrinxâ without compromising growth performance and body composition. Our results indicate that locally produced sacha inchi seeds have the potential to substitute more expensive non-regional sources of PUFA in tambaqui and matrinxã diets in Amazonian aquaculture.

\section{ACKNOWLEDGEMENTS}

To Irani da Silva de Morais, research assistant at Embrapa Amazônia Ocidental, for her invaluable contribution with water quality analyses, and Daniela Nomura Varandas, fish farming technician of Trouw Nutrition, a Nutreco company, for supplying the vitamin and mineral mix composition.

\section{REFERENCES}

Almudi, T.; Pinheiro, J.O.C. 2015. Dados estatísticos da produção agropecuária e florestal do Estado do Amazonas: Ano 2013. Editora Embrapa, Brasília, 105p.

Arbeláez-Rojas, G.A.; Fracalossi, D.M.; Fim, J.D.I. 2002. Composição corporal de tambaqui, Colossoma macropomum, e matrinxã, Brycon cephalus, em sistemas de cultivo intensivo, em igarapé, e semi-intensivo, em viveiros. Revista Brasileira de Zootecnia, 31: 1059-1069.

Arbeláez-Rojas, G.A.; Inoue, L.A.K.A.; Moraes, G. 2011. Atividade proteolítica e crescimento de matrinxã em natação sustentada $\mathrm{e}$ alimentado com dois níveis de proteína. Pesquisa Agropecuária Brasileira, 46: 1521-1529.

Aride, P.H.R.; Roubach, R.; Val, A.L. 2007. Tolerance response of tambaqui Colossoma macropomum (Cuvier) to water $\mathrm{pH}$. Aquaculture Research, 38: 588-594.

Catalán, J.S.; Aguero, S.D.; García, J.T. 2015. Los ácidos grasos dietarios y su relación com la salud. Nutrición Hospitalaria, 32: 1362-1375.

Clavijo, D.B.; Rodríguez, F.V.; Estupiñán, J.E.C. 2015. Utilización de Plukenetia volubilis (sacha inchi) para mejorar los componentes nutricionales de la hamburguesa. Enfoque, 6: 59-76.
Céspedes, E.I.M. 2006. Cultivo de sacha inchi. Instituto Nacional de Investigación y Extensión Agraria, Ministério de Agricultura, San Martín, Peru, 11p.

Chagas, E.C.; Pilarski, F.; Sakabe, R.; Moraes, F.R. 2013. Desempenho produtivo e respostas fisiopatológicas de tambaquis alimentados com ração suplementada com $\beta$-glucano. Pesquisa Agropecuária Brasileira, 48: 899-905.

Dairiki, J.K.; Silva, T.B.A. 2011. Revisão de literatura: exigências nutricionais do tambaqui - compilação de trabalhos, formulação de ração adequada e desafios futuros. Documento 91, Embrapa Amazônia Ocidental, Manaus, Brazil, 44p.

Dairiki, J.K.; Correa, R.B.; Inoue, L.A.K.A.; Morais, I.S. 2013. Feijão-caupi autoclavado na nutriçáo de juvenis de tambaqui. Pesquisa Agropecuária Brasileira, 48: 450-453.

Fanali, C.; Dugo, L.; Cacciola, F.; Beccaria, M.; Grasso, S.; Dacha, M.; Dugo, P.; Mondello, L. 2011. Chemical characterization of sacha inchi (Plukenetia volubilis L.) oil. Journal of Agricultural and Food Chemistry, 59: 13043-13049.

Garcia, A.S.; Gonçalves, L.U.; Cavalli, R.O.; Viegas, E.M.M. 2012. Lipídios. In: Fracalossi, D.M.; Cyrino, J.E.P. (Ed.). Nutriaqua: nutrição e alimentação de espécies de interesse para a aquicultura brasileira. Sociedade Brasileira de Aquicultura e Biologia Aquática, Florianópolis, Brazil, p.79-100.

Garmendia, F; Pandos, R; Ronceros, G. 2011. Efecto del aceite de sacha inchi (Plukenetia volubilis $\mathrm{L}$ ) sobre el perfil lipídico en pacientes com hiperlipoproteinemia. Revista Peruana de Medicina Experimental y Salud Publica, 28: 628-632.

Gomes, L.C.; Simões, L.N.; Araújo-Lima, C.A.R.M. 2005. Tambaqui (Colossoma macropomum). In: Baldisserotto, B.; Gomes, L.C. (Ed.). Espécies nativas para piscicultura no Brasil. Editora UFSM, Santa Maria, Brazil, p.175-204.

Gomes, L.C.; Urbinatti, E.C. 2005. Matrinxã (Brycon amazonicus). In: Baldisserotto, B.; Gomes, L.C. (Ed.). Espécies nativas para piscicultura no Brasil. Editora UFSM, Santa Maria, Brazil, p.149-174.

Gorriti, A.; Arroyo, J.; Quispe, F.; Cisneros, B.; Condorhuamán, M.; Almora, Y.; Chumpitaz, V. 2010. Toxicidad oral a 60 días del aceite de sacha inchi (Plukenetia volubilis L.) y linaza (Linum usitatissimum L.) y determinación de la dosis letal 50 en roedores. Revista Peruana de Medicina Experimental y Salud Publica, 27: 352-360.

Guillén, M.D.; Ruiz, A.; Cabo, N.; Chirinos, R.; Pascual, G. 2003. Characterization of Sacha Inchi (Plukenetia volubilis L) oil by FTIR spectroscopy and H NMR. Comparison with linseed oil. Journal of the American Oil Chemists' Society, 80: 775-762.

Gutiérrez, L.F.; Rosada, L.M.; Jiménez, A. 2011. Chemical composition of Sacha Inchi (Plukenetia volubilis L.) seeds and characteristics of their lipid fraction. Grasas Aceites, 62: 76-83.

Honczaryk, A.; Inoue, L.A.K.A. 2009. Produção comercial de alevinos de matrinxã na Amazônia Ocidental. Circular Técnica 33, Embrapa Amazônia Ocidental, Manaus, Brazil, 7p.

Instituto Brasileiro de Geografia e Estatística. 2015. Produção da Pecuária Municipal. IBGE, 43: 17p. 
Izel, A.C.U.; Pereira-Filho, M.; Melo, L.A.S.; Macêdo, J.L.V. 2004. Avaliação de níveis proteicos para a nutrição de juvenis de matrinxã (Brycon cephalus). Acta Amazonica, 34: 179-184.

Jacometo, C.B.; Barrero, N.M.L.; Rodriguez-Rodriguez, M.P.; Gomes, P.C.; Povh, J.A.; Streit Junior, D.P.; Vargas, L.; Resende, E.K.; Ribeiro, R.P. 2010. Variabilidade genética em tambaquis (Teleostei: Characidae) de diferentes regióes do Brasil. Pesquisa Agropecuária Brasileira, 45: 481-487.

Jobling, M.; Leknes, O.; Saether, B.J.; Bendiksen, E.A. 2008. Lipid and fatty acid dynamics in Atlantic cod, Gadus morhua, tissues: influence of dietary lipid concentrations and feed oil sources. Aquaculture, 281: 87-94.

Kamarudin, M.S.; Ramezani-FARD, E.; Saad, C.R.; Harmin, S.A. 2012. Effects of dietary fish oil replacement by various vegetable oils on growth performance, body composition and fatty acid profile of juvenile mahseer, Tor tambroides. Aquaculture Nutrition, 18: $532-543$.

Maurer, N.E.; Hatta-Sakoda, B.; Pascual-Chagman, G.; RodriguezSaona, L.E. 2012. Characterization and authentication of a novel vegetable source of omega-3 fatty acids, sacha inchi (Plukenetia volubilis L.) oil. Food Chemistry, 134: 1173-1180.

New, M.B. 1987. Feed and feeding of fish and shrimp. ADCP/ REP/87/26, UNDP, FAO, Rome, Italy, 275p.

Oishi, C.A.; Nwanna, L.W.; Pereira Filho, M. 2010. Optimum dietary protein requirement for Amazonian Tambaqui, Colossoma macropomum Cuvier, 1818, fed fish meal free diets. Acta Amazonica, 40: 757-762.

Portz, L.; Furuya, W.M. 2012. Energia, proteína e aminoácidos. In: Fracalossi, D.M.; Cyrino, J.E.P. (Ed.) Nutriaqua: nutrição e alimentação de espécies de interesse para a aquicultura. Editora Sociedade Brasileira de Aquicultura e Biologia Aquática, Florianópolis, Brazil, p.65-77.

Rodríguez, G.; Villanueva, E.; Glorio, P.; Baquerizo, M. 2015. Estabilidad oxidativa y estimación de la vida útil del aceite de sacha inchi (Plukenetia volubilis L.). Scientia Agropecuaria, 6: 155-163.

Sebrae. 2015. Aquicultura no Brasil: Série estudos mercadológicos. Brasília, Brazil, 76p.

Silva, A.M.D.; Gomes, L.C.; Roubach, R. 2007. Growth, yield, water and effluent quality in ponds with different management during tambaqui juvenile production. Pesquisa Agropecuária Brasileira, 42: 733-740.
Silva, C.A.; Fujimoto, R.Y. 2015. Crescimento de tambaqui em resposta a densidade de estocagem em tanques-rede. Acta Amazonica, 45: 323-332

Souza, A.H.P.; Gohara, A.K.; Rodrigues, A.C.; Souza, N.E., Visentainer, J.V.; Matsushita, M. 2013. Sacha inchi as potential source of essential fatty acids and tocopherols: multivariate study of nut and shell. Acta Scientiarum. Technology, 35: 757-763.

Stone, D.A.J.; Oliveira, A.C.M.; Ross, C.F.; Plante, S.; Smilley, S.; Bechtel, P.; Hardy, R.W. 2011. The effects of phase-feeding rainbow trout (Oncorhynchus mykiss) with canola oil and Alaskan Pollock oil on fillet fatty acid composition and sensory attributes. Aquaculture Nutrition, 17: 521-529.

Tanamati, A.; Stevanato, F.B.; Visentainer, J.E.L.; Matsushita, M.; Souza, N.E.; Visentainer, J.V. 2009. Fatty acid composition in wild and cultivated pacu and pintado fish. European Journal of Lipid Science and Technology, 111: 183-187.

Turchini, G.M.; Francis, D.S. 2009. Fatty acid metabolism (desaturation, elongation and $\beta$-oxidation) in rainbow trout fed fish oil-based diets. British Journal of Nutrition, 102: 69-81.

Urbinati, E.C.; Sarmiento, S.J.; Takahashi, L.S. 2014. Shortterm cycles of feed deprivation and refeeding promote full compensatory growth in the Amazon fish matrinxã (Brycon amazonicus). Aquaculture, 433: 430-433.

Valenzuela, B.R.; Barreira, R.C.; Gonzáles-Astorga, M.; Sanhueza, C.J.; Valenzuela, B.A. 2014. Alpha linolenic acid (ALA) from Rosa canina, sacha inchi and chia oils may increase ALA accretion and its conversion into n-3 LCPUFA in diverse tissues of the rat. Food \& Function, 5: 1564-1572.

Vargas, R.J.; Souza, S.M.G.; Kessler, A.M.; Baggio, S.R. 2008. Replacement of fish oil in diets for jundiá (Rhamdia quelen Quoy \& Gaimard 1824): effects on performance and whole body fatty acid composition. Aquaculture Research, 39: 657-665.

RECEIVED: $13 / 03 / 2017$

ACCEPTED: 19/09/2017

ASSOCIATE EDITOR: Marcos Tavares-Dias 